\title{
DE OPHEFFING DER STRAFKOLONIE IN FRANSCH GUYANA EN HAAR MOGELIJKE GEVOLGEN VOOR SURINAME
}

DOOR

MR. O. E. G .GRAAF VAN LIMBURG STIRUM

De berichten, welke in den laatsten tijd in de pers de ronde doen omtrent een opheffing van de strafkolonie in Fransch Guyana, maken het noodzakelijk, zich er rekenschap van te geven, welke daarvan de gevolgen voor Suriname kunnen zijn.

Zoolang de kampen van St. Laurent en omgeving bestaan, is het aantal ontvluchtingen bij de gestraften steeds groot geweest. De betrekkelijk zwakke bewaking, de aanwezigheid van rivieren en oerbosschen, de nabijheid van vreemde landen en niet het minst de toestand, waarin de bevolking der strafkolonie verkeert, hebben er toe bijgedragen, dat velen plannen beraamden, om in betere omgeving hun geluk te beproeven, en dat vele dier plannen in zooverre ten uitvoer konden worden gelegd, dat inderdaad het grondgebied van een vreemden staat (meestal Suriname) werd bereikt, wat natuurlijk allerminst impliceert, dat ook een betere omgeving en geluk het deel der vluchtelingen werd.

De oerwouden, rivieren en kreken van Suriname zijn stille getuigen van de meest ontzettende ontberingen, van hopeloozen strijd tegen wilde dieren, insecten en ziekten, vaak ook van afgrijselijke tooneelen van moord en roofzucht tusschen lotgenooten, van bovenmenschelijke inspanning en algeheele uitputting, van gruwelijken doodstrijd in een onmetelijke eenzaamheid.

Doch dit alles heeft noch de menschen, die achterbleven, noch ook hen, die na al die gevaren getrotseerd te 
hebben en daarna door de Surinaamsche autoriteiten na aanhouding naar de strafkolonie te zijn teruggezonden, kunnen weerhouden, telkens weer hun kans op bevrijding te wagen.

De houding van het Surinaamsche Gouvernement ten aanzien van deze ,évadés" heeft zich tot voor kort niet door een vaste lijn gekenmerkt. Hoewel men steeds van het recht tot ,uitzetting" kon gebruik maken ${ }^{\mathbf{1}}$ ), heeft men sommigen geduld, anderen na eenigen tijd, wanneer zij voor de algemeene rust of veiligheid gevaarlijk werden, teruggezonden, de meesten echter terstond na hun aanhouding op transport naar St. Laurent gesteld.

Uiteraard was deze houding wel begrijpelijk. Velen der ontvluchten waren goede ambachtslieden, die in Surinamenu niet bepaald in groote getale aanwezig zijn, anderen konden door winkelnering in hun onderhoud voorzien en weer anderen als huisbedienden werkzaam zijn. Zeer velen echter bleken in een vreedzame samenleving niet op hun plaats en bleven dus steeds gevaarlijke elementen. Toen dan ook in 1922 het aantal ernstige misdrijven tegen leven en goed van Surinaamsche burgers toenam, heeft het Gouvernement terecht gemeend, scherper tegen de z.g. „déportés” te moeten optreden. Dit kwam niet alleen de inheemsche burgerij en de rustige elementen onder die „déportés" ten goede, maar strekte tevens tot waarschuwing van de bevolking der strafkolonie, welke veelal de meening was toegedaan, dat men het in Suriname te dezen opzichte zoo nauw niet nam. Het resultaat van dit optreden was, dat de bewaking in de strafkolonie zou worden verscherpt en dat geregeld transporten gevangenen door den Franschen Penitentiairen Dienst in Paramaribo zouden worden afgehaald, terwijl natuurlijk de vluchtelingen, die in het grensdistrict Marowijne waren aangehouden,geregeld zouden worden uitgezet, zooals reeds gebruikelijk was ${ }^{2}$ ).

\footnotetext{
1) De gevallen, waarin ,uitlevering” mogelijk was, zijn natuurlijk steeds in de minderheid geweest.

2) Over nadere bijzonderheden hieromtrent moge ik verwijzen naar een artikel van mijn hand, opgenomen in het nummer van Juni 1923 van dit tijdschrift.
} 
Hoe zal het nu echter in de toekomst gaan? Er zijn twee mogelijkheden: òf de Fransche Regeering besluit tot algeheele opheffing van de strafkolonie en tot terugzending van alle thans daar nog aanwezige gestraften naar Frankrijk, òf zij zal er alleen toe overgaan, geen nieuwe transporten meer te zenden en ten aanzien van de aanwezigen het z.g. "uitstervingssysteem” toe te passen.

Het is vrij onwaarschijnlijk, dat de eerste gedragslijn zal worden gevolgd, omdat daaraan zeer hooge transportkosten zouden zijn verbonden, waartoe een regeering bij de thans alom gewenschte beperking van staatsuitgaven wel moeilijk zal durven besluiten, terwijl daarbij dan nog komen de kosten voor incarcereering in Frankrijk. De transportkosten zouden bij een bevolking van \pm 5.000 „transportés”, \pm 1500 „rélégués” en \pm 500 ,libérés” ongeveer 5 millioen francs beloopen, terwijl vermoedelijk schadevergoeding zou moeten worden betaald aan de maatschappij, met welke een contract voor het vervoer der gestraften is gesloten en welke daartoe een speciaal daarvoor ingericht vaartuig heeft laten bouwen. Deze maatregel zou ten aanzien van Suriname geen toestanden scheppen, welke een bespreking noodzakelijk maken. Suriname zou bevrijd worden van een naburige bevolking, welke voortdurende bedachtzaamheid en geregeld toezicht vereischt en zou, daar van handeldrijven met de strafkolonie feitelijk geen sprake is, van dien maatregel ook geen nadeelige doch slechts voordeelige gevolgen ondervinden.

Rest dus het beschouwen van de andere mogelijkheid, de toepassing van het ,uitstervingssysteem”. Geredelijk kan worden aangenomen, dat, waar de bewaking tot nu toe reeds vrij slap was, hierin zeker geen verbetering zal komen, wanneer de Fransche autoriteiten weten, dat de bevolking toch moet verloopen. Hoe eerder dit dan heeft plaats gehad, hoe beter en voordeeliger voor de staatskas. Het administratieve- en het bewakingspersoneel kan geleidelijk worden ingekrompen, terwijl van den voorgestelden kostbaren aanleg van een muur om het kamp van St. Jean natuurlijk niets meer zal komen. Het aantal ont- 
vluchtingen zal niet alleen daardoor toenemen, maar ook doordat de gestraften thans nog meer dan voorheen zullen trachten, de steeds begeerde vrijheid deelachtig te worden. Zoolang zij immers nog in deze streken zijn, verkeeren zij in een gunstiger positie dan hun "collega's", die in Frankrijk worden (en in casu zullen worden) opgesloten, wijl hier de kans op ontvluchting en vrijheid grooter is dan daar. En nu moge het Surinaamsche Gouvernement zich al blijven beroepen op de overeenkomst van het voorjaar van 1923 ten aanzien van de bewaking der gestraften en het transport der gevluchten, tegen een eenigszins systematisch toegepaste lijdelijkheid der Fransche autoriteiten zal men tenslotte weinig vermogen. Doch hoe dan ook, men zal goed doen, te overwegen, welke beveiligingsmaatregelen moeten worden genomen. Als zoodanig komt dan feitelijk alleen in aanmerking een verscherpt optreden door de militairen. Men zal in de eerste plaats moeten overgaan tot het stationneeren van militaire troepenafdeelingen langs de geheele Marowijne, omdat de oeverstreken van deze rivier vele gelegenheden bieden voor nederzettingen van „marodeurs". De „placers” van de „Compagnie des mines d'or" worden nu reeds militair bewaakt, zoodat daar hoogstens een kleine versterking noodig zou zijn. Maar vooral de patrouilles voor de bosschen in den omtrek van Moengo en in de nabijheid der dichter bij Paramaribo gelegen plantages en vestigingsplaatsen zoowel als voor die verschillende plaatsen en Paramaribo zelf zouden moeten worden versterkt. Deze patrouilles doen inderdaad reeds nu een zeer nuttig werk, maar hun taak zou natuurlijk in de toekomst aanmerkelijk verzwaard worden. Ten behoeve van de noodige aflossingen dier patrouilles zal men dus over een behoorlijk contingent aan troepen moeten beschikken. Aan overheveling van militairen naar de politie zal dan ook niet kunnen worden gedacht, zoolang de eersten voor de hierboven omschreven doeleinden noodig zijn en zeker niet, wanneer men ertoe zou overgaan, het aantal militairen in te krimpen. Tegen dit laatste moge dan ook worden gewaarschuwd. De negers zijn als regel vreedzame 
lieden, maar de Surinaamsche bevolking bevat daarnaast elementen, welke voor de algemeene rust gevaarlijk zijn of kunnen worden en waartegen men op zijn hoede behoort te wezen, temeer, wanneer het zich laata anzien, dat hun aantal zal toenemen. Daarom dient ernstig te worden gewaarschuwd tegen pogingen, welke - hoewel mogelijk onbedoeld - zouden kunnen leiden tot een verzwakking van ons gezag en een vermindering van de veiligheid in Suriname. Zoo zou de zuinigheid wel eens kunnen blijken de wijsheid te bedriegen! Met de thans aanwezige troepenmacht van nog geen 200 man zal het dan ook niet mogelijk blijken, afdoende maatregelen ter beveiliging tegen een groeiend aantal vluchtelingen uit de Fransche strafkolonie te nemen.

Tenslotte dringen zich enkele vragen naar voren, waarop een antwoord nog niet is te geven, doch welker beschouwing voor onze in de toekomst te dezen aanzien te volgen gedragslijn van belang kan zijn.

In de eerste plaats: wil Frankrijk thans is haar ZuidAmerikaansche kolonie ,echt” gaan koloniseeren? Zal zij daarheen krachtige en deskundige kolonisten zenden, of voortsukkelen met de treurige werkkrachten, waarmede zij tot nu toe meende, iets tot stand te kunnen brengen? Of zal men bij toepassing van het „uitstervingsstelsel” den menschen zoodanige rechten en mogelijkheden verschaffen, dat zij geen behoefte tot vluchten zullen gevoelen? Zal men voor hen wellicht de kans op een spoedigen terugkeer naar Frankrijk openstellen?

Mocht inderdaad een degelijk plan van kolonisatie worden overwogen, dan komt men voor de vraag te staan, of het Gouvernement dier kolonie dan nog prijs zal stellen op de aanwezigheid van zoovele ex-misdadigers. Deze zijde van het vraagstuk is voor de Surinaamsche Regeering van zeer veel belang, want zij - en met haar de Nederlandsche Regeering - zal zich vooraf ervan hebben te overtuigen, welk stadpunt men in de naburige kolonie zal innemen ten aanzien van door Suriname ,uitgezette ongewenschte vreemdelingen". Het zou zeer goed mogelijk kunnen zijn, dat men, de kolonisatie goed willende aan- 
vatten, die elementen niet meer begeerde. Waarheen moet Suriname dan uitzetten? Naar Frankrijk? Maar wie betaalt dan de transportkosten?

Inderdaad heeft het vraagstuk der eventueele opheffing van de strafkolonie in Fransch Guyana vele zijden, welke alle ernstig moeten worden bezien en het wil mij voorkomen, dat behalve het Departement van Koloniën ten aanzien van de uitbreiding van het troepencontingent ook het Departement van Buitenlandsche Zaken ten aanzien van onderwerpen van internationaal recht ten dezen een taak heeft, welke werkelijk niet zonder gewicht is. Men bezie ook deze kwesties in het licht van de toekomst en bedenke, welk een groot belang voor Nederland is gelegen in een veilig, rustig en welvarend gebiedsdeel in Zuid-Amerika.

Bloemendaal, October 1924. 